\title{
Dylematy współczesnej edukacji moralnej
}

\section{Streszczenie}

Artykuł dotyczy sytuacji w polskiej oświacie, w której edukacja moralna nie jest prowadzona według jednolitego modelu, lecz realizowana dwutorowo, w postaci fakultatywnych zajęć programowych $\mathrm{z}$ religii oraz etyki. $\mathrm{W}$ takich uwarunkowaniach zajęcia realizowane w ramach tych przedmiotów stanowią względem siebie konkurencyjną ofertę, choć w swej istocie dotyczą tych samych treści programowych. Autor odróżnia wychowanie moralne od edukacji moralnej, wychodząc z założenia, że takie wychowanie jest realizowane w zasadzie wyłącznie w domu rodzinnym, a zadaniem szkoły jest tylko wzbogacenie umiejętności dokonywania wyborów moralnych przez młode pokolenie. Szkoła nie może zatem ponosić winy za kondycję moralną uczniów, którą kształtuje szeroko rozumiane środowisko domowe.

Słowa kluczowe: etyka, religia, edukacja moralna, wychowanie religijne, społeczeństwo konsumpcyjne, postęp kulturowy

DOI: $10.33119 / \mathrm{KSzPP} / 2019.4 .6$

\section{The dilemmas of the present moral education}

\begin{abstract}
The article relates to the situation in the Polish education, where moral education is taught as two school subjects: either religious education or ethics. Although the subjects are in direct competition, essentially, they relate to the same curriculum content. The author distinguishes moral upbringing from moral education, by assuming that the upbringing is carried out mainly at home, whereas the school's aim is to support the skills of making moral choices by the young generation. Therefore, the school cannot be blamed for pupils' moral condition because it is shaped by the home environment, which is understood in a wide sense here.
\end{abstract}

Keywords: ethics, religion, moral education, religious upbringing, consumer society, cultural progress

1 Uniwersytet Zielonogórski 
$\mathrm{W}$ debatach nad różnymi zagadnieniami związanymi z młodym pokoleniem zamiennie wykorzystywane są pojęcia: „wychowanie moralne” oraz „edukacja moralna ${ }^{2 \prime}$. Przyjmuję, że to pierwsze jest realizowane przede wszystkim w domu rodzinnym i jest swego rodzaju ukierunkowaniem wychowanka przez wpojone mu wartości, którymi powinien się kierować w życiu. Edukacja moralna zaś jest realizowana instytucjonalnie, a więc zwłaszcza w szkole. Zakładam, że tam zajęcia z tej dziedziny powinny być z założenia pluralistyczne (nieangażujące światopoglądowo). Ponadto istotną kwestią wydaje się to, do jakiego stopnia należałoby uznać szkołę za instytucję ponoszącą odpowiedzialność za kondycję moralną młodego pokolenia. Na pewno powinna wskazywać na aprobowane społecznie możliwości wyboru w kształtowaniu postaw moralnych.

Istotna jest kwestia definiowania edukacji moralnej w Polsce. Wydaje się, że ciągle słychać echo okresu zaborów, kiedy za najważniejszy cel wychowawczy uznawano utrzymanie jedności społeczeństwa rozdartego przez sąsiadów. A. Rosiękowiczowa pisała, że „Nauka moralna, jest zebranie prawideł, podług których ma postępować każdy człowiek w społeczeństwie" (Rosiękowiczowa, 1823:3)³. Jej podejście zakłada, że wszyscy ludzie są jednakowo podatni na wpływy wychowawcze, a więc każdego można wszystkiego nauczyć. Ludzie jednak nie są jednakowi i należy założyć, że edukacja moralna musi zawierać przekaz pożądanych społecznie wartości, ale z pewnością nie wszyscy je zaakceptują.

Dlatego do potrzeb instytucjonalnego wychowania przydatniejsza jest definicja, która z góry nie zakłada ujednolicania poglądów i przekonań wychowanków, jak ta na przykład autorstwa A. Zybały, który podkreśla, że szeroko rozumiana edukacja moralna oznacza zbiór działań publicznych (zbiorowych) służących powiększaniu zasobów tak zwanego kapitału niekognitywnego, czyli zbioru umiejętności pozapoznawczych (non-cognitive skills, social and emotional skills) (Zybała, 2019). W tym podejściu autor nie zakłada wyposażania młodego pokolenia w identyczne wartości i schematy. Wskazuje natomiast na upowszechnianie wspólnych wzorców moralnych, które przywoływane są często w anglosaskiej literaturze dotyczącej edukacji moralnej (okazywanie szacunku innym oraz dorobkowi społecznemu, uczciwość, życzliwość itp.).

\footnotetext{
2 W poniższych rozważaniach pojęcie edukacji moralnej można zamiennie stosować z pojęciem edukacji etycznej, jeśli nie nadaje się mu jakiegoś specyficznie odmiennego znaczenia.

3 We wszystkich cytatach zachowano pisownię oryginałów.
} 


\section{Bariery i szanse}

Zreformowanie jakiejś dziedziny życia społecznego wymaga próby określenia tego, co się chce zmienić oraz wskazania celu do osiągnięcia. Wydaje się, że w przypadku szkolnej edukacji moralnej nie istnieje żaden jej autonomiczny system w polskich szkołach, co oczywiście nie znaczy, że nie jest ona w nich prowadzona. Nie prowadzi jej również katecheza (religia), bo jej głównym celem nie jest przecież sama poprawa kondycji moralnej społeczeństwa, ale tak naprawdę podtrzymywanie istniejącego stanu rzeczy, w którym zajmuje ona uprzywilejowaną pozycję. Nie można zatem mówić o konkurencyjności religii i etyki w sferze wychowania moralnego, bo w swej istocie realizują one inne cele. Ideałem jednak byłoby, gdyby młodzież uczestniczyła zarówno w jednej, jak i w drugiej formie edukacji, dzięki czemu miałaby do dyspozycji więcej ofert wyboru dróg życiowych.

Nie można jednak nie uwzględniać wpływu przedstawicieli polityki na edukację moralną. Problem z jej wprowadzeniem ma związek z samym celem, któremu miałaby służyć. Pedagodzy ciągle chcą ją realizować wedle jakiegoś idealnego wzorca ukształtowanego w zasadzie jeszcze w okresie pozytywizmu, a więc dążą do ukształtowania człowieka uniwersalnego, słowem prawdziwego obywatela świata. A z punktu widzenia przedstawicieli instytucji władzy jest to cel niepożądany, bo tacy obywatele stwarzają tylko problemy, wysuwając żądania dotyczące wprowadzania określonego porządku społecznego, którego politycy wcale nie muszą pożądać.

Dla przedstawicieli władzy ideałem byłby obywatel akceptujący zastany porządek społeczny i nieoczekujący wprowadzania w nim jakichkolwiek zmian. Zderzenie tych dwóch oczekiwań powoduje, że postulaty wysuwane przez pedagogów rozmijają się istotnie z oczekiwaniami władz politycznych. W efekcie władza wspiera te propozycje, które najlepiej odpowiadają jej interesom. Nie powinno zatem nikogo dziwić dowartościowywanie wszelkich form edukacji moralnej realizowanej na zajęciach z religii, bo na tych zajęciach nikt nie kształtuje przecież przyszłych rewolucjonistów.

Również rodzina nie gwarantuje prowadzenia edukacji moralnej skierowanej ku przyszłości. Już Arystoteles zauważył trafnie, że rodzina jest jakby miniaturą organizmu państwowego, a zatem jej działania w tej sferze są w znaczącej mierze zbieżne z interesami władzy politycznej. Nie znaczy to oczywiście, że w rodzinie nie prowadzi się szeroko zakrojonego wychowania moralnego, ale nie jest ono nastawione na zmianę istniejącego porządku rzeczy, bo także przede wszystkim na jego utrwalanie. Już z tych racji niezbicie wynika, że sfera wychowania moralnego nie powinna się ograniczać wyłącznie do rodziny ani też do działań podejmowanych przez zmieniające się w rytmie wyborów władze oświatowe. Powinna zatem istnieć 
jakaś niezależna od nich instytucja przygotowująca zarówno społeczeństwo, jak i jego instytucje do wyzwań, które przynieść może nieodległa przyszłość. Wychowankowie nastawieni tylko na powielanie istniejących rozwiązań będą mieli trudności w tym, aby odnaleźć się w zupełnie nowych warunkach, na przykład w przypadku zmiany władz politycznych. A na dodatek nastawieni głównie na kontynuację będą, np. w przypadku choćby tylko czasowej emigracji, podatni na przejęcie nad nimi kontroli przez bardziej dynamiczne społeczności, które zdążyły się do takich zmian odpowiednio wcześniej przygotować.

Można nawet stwierdzić, że jeszcze w rzeczywistości tzw. realnego socjalizmu rodzina i wychowanie religijne spełniały funkcje modernistyczne, gdyż przygotowały całe młode pokolenie, wbrew oczekiwaniom władz politycznych, do rzeczywistości demokracji liberalnej jako pewnego stanu pożądanego. Interesującym spostrzeżeniem jest, że z chwilą nastania nowego porządku społecznego nowa, ta niegdyś pożądana, rzeczywistość społeczna szybko zaczęła być postrzegana jako źródło zagrożeń i całe nieinstytucjonalne wychowanie moralne zatraciło swój impet, zadowalając się połowicznymi rozwiązaniami i skutecznie wyhamowując impet niezbędny do dokonywania zmian.

\section{O potrzebie instytucjonalnej edukacji etycznej}

Barierą dla instytucjonalnie realizowanej edukacji moralnej jest jeszcze inne zjawisko. Otóż współczesna młodzież nie jest już kształtowana długofalowo w procesach dydaktycznych. Ma miejsce inny proces - swoista „tresura” przez wszechogarniający system oparty na przekazie hipertekstowym ${ }^{4}$. Współczesny smartfon czy laptop angażuje bowiem bez reszty całą uwagę użytkownika. Nie potrzebuje on żadnych bezpośrednich kontaktów społecznych, aby mieć wrażenie, że jest aktywnym uczestnikiem życia. Jego tresura polega na tym, że jeśli nie będzie podążał za głównym strumieniem, to system sam z siebie ograniczy mu dostęp albo wręcz pozbawi go możliwości uczestniczenia w jego funkcjonowaniu.

Ta tresura odbywa się dokładnie na tej samej zasadzie, co poruszanie się szczura szukającego drogi wyjścia w labiryncie, który jest „nagradzany” za pewne wybory, ale zarazem „karany” za inne. Nie są to katastroficzne rozważania współczesności,

4 Na temat źródeł kryzysu instytucji wychowania moralnego trafnie wypowiedział się Tadeusz Pilch. Podkreślał, że kryzys epoki druku łamie dotychczasową rzeczywistość pedagogiczną opartą „na słowie drukowanym, które ukształtowało filozofię i metodykę współczesnej szkoły, które nadało specyficzną rangę nauczycielowi, a proces socjalizacji nieomal całkowicie utożsamiło z procesem dydaktycznym" (Pilch, 1999: 57). 
bo pisał o nich już Karl Polanyi w słynnej książce The Great Transformation (1944), w której między innymi rozważał przyczyny sukcesów faszyzmu w Europie (Polanyi, 2001:245.). Uproszczona wizja świata, jaką oferuje tzw. społeczeństwo sieciowe, skłaniać też musi do trywializacji przyczyn, dzięki którym ono funkcjonuje. Rozwiązania totalitarne były oparte na kulcie wyabstrahowanej dzięki zabiegom propagandowym jednostki, która działając w zbiorowości podobnych sobie, wszystko mogła, wszystko wiedziała i do wszystkiego miała prawo. Czym zatem grozi nam społeczeństwo ukształtowane bez wyraźnych drogowskazów i jasno określonych autorytetów? Dziś mamy zbliżoną społeczną sytuację, gdyż garstka opętanych jakąś chorą ideologią byłaby w stanie zawładnąć całym systemem bez większego oporu biernej większości, demontując, podobnie jak to zrobili przed stu laty naziści, wszystkie wydawałoby się niewzruszalne instytucje demokratycznego państwa.

Reguły tresury nie są bowiem przypadkowe. Otóż wypada się zgodzić z tezą Polanyiego, że są one pochodną dominacji zasad rynkowych nad mechanizmami kierującymi demokratycznym organizmem politycznym. W rezultacie, jak zauważył Polanyi, państwo uznawane zostawało za demokratyczne tylko wówczas, gdy główną rolę w nim odgrywał bank centralny. Doprowadziło to do niespotykanej wcześniej standaryzacji społeczeństw, gdyż wszystkie zaczęły się kierować analogicznymi zasadami wewnętrznej organizacji (Polanyi, 2001: 261).

Tym samym wszędzie tam, gdzie wszystko jest regulowane, prawdziwej wolności po prostu nie ma i być nie może. A tak było przecież w obu ustrojach totalitarnych - komunizmie i faszyzmie. Dlatego Polanyi twierdził, że społeczeństwo demokratyczne musi być stać na luksus wolności. Przytaczał słowa socjalisty utopijnego Roberta Owena, że to sam człowiek, a nie bezduszne instytucje, musi mieć wpływ na zakres swojej wolności, inaczej wszystkie jego skargi będą nieskuteczne, przez to w ogóle już nikt nie będzie protestował przeciwko nakładanym ograniczeniom (Polanyi, 2001: 268).

Potwierdzeniem słuszności tez Polanyiego zdaje się być sytuacja obecna, w której zaaferowane swoimi sprawami społeczeństwo coraz mniej uwagi poświęca młodemu pokoleniu. Tak naprawdę rodzice często są w pewnym stopniu zadowoleni, gdy ich dzieci im nie przeszkadzają, funkcjonując w świecie równoległym i tworząc nieomal stałe elementy społeczeństwa sieciowego. Młode pokolenia w pewnym sensie przestały być już częścią tradycyjnej kultury, bo w ocenie innych liczy się pozór, zewnętrzny blichtr, a nie zdolność do pomnażania kultury. Ten rozpad na kulturę starą i nową miał co prawda zawsze miejsce w historii, gdyż w znaczącym stopniu warunkował rozwój kultury ogólnoludzkiej, która była pomnażana dzięki swoistej niezgodzie młodego pokolenia na niektóre przynajmniej wartości kultury dotychczasowej. Współcześni rodzice i wychowawcy tak naprawdę jednak nie wiedzą, czego 
z ich świata nie akceptują ich własne dzieci. Młodzież też ma kłopot z określeniem własnych priorytetów, przez co jest niesłusznie określana mianem pokolenia konformistycznego i pozbawionego ideałów. Tymczasem jesteśmy zapewne świadkami tworzenia się nowej formacji kulturowej, która już niczego nie będzie modyfikować, ale radykalnie zmieni istniejącą kulturę, a symptomy tego są dostrzegalne już teraz. „Nie jest to już kultura hierarchiczna, prawomocna [...] lecz [...] kultura mozaikowa, zdecentralizowana, bez hierarchii i punktów centralnych” (Krzysztofek, 2001: 40).

W takiej formacji kulturowej tracą na znaczeniu wykształcenie, aspiracje życiowe, bo liczy się prawdopodobnie tylko umiejętność samodzielnego radzenia sobie w życiu. Nawet to, że młodzi maksymalnie wydłużają okres zamieszkiwania z rodzicami, jest tego elementem. Być może młodzi nie będą już potrzebować urzędów, instytucji, bo to, co jest im potrzebne do przetrwania, znajdą w sieci. A jeśli tego nie potrafią, to sami siebie wyrzucą poza obręb społeczeństwa. Umiejętność korzystania z bankowości elektronicznej jest już zapewne ważniejsza od znajomości arytmetyki, geometrii czy astronomii.

\section{Kondycja moralna młodego pokolenia}

Musimy zatem już teraz diagnozować kondycję moralną młodego pokolenia, a nawet charakteryzować kulturę, którą wnosi w obręb społeczności. Teraz nadszedł czas, aby zastanowić się nad tym, jak zadbać o to, by owo radzenie sobie w życiu nie stało w sprzeczności z wartościami ogólnoludzkimi. „Siłą tej kultury jest produkcja mód, bez nich ona nuży, są to [...] »jednominutowe trendy«. W tej»kulturze bez historii« jest wieczna obecność, »człowiek posthistoryczny«, w przeciwieństwie do tradycyjnej, w której była obecna wieczność. Świadomość ludzi obejmuje coraz mniejszą skalę przeszłości, zaś horyzont przyszłości zamyka się w perspektywie kilku lat (kultura typu instant do natychmiastowego spożycia i wydalenia). Słabość tej kultury i człowieka w niej polega nie tyle na braku edukacji, co na zanikaniu w homo consumens pierwiastka thymos" (Krzysztofek, 2001: 41). Atomizujące się młode pokolenie przy zaniku osobistych kontaktów zaczyna być już nie tyle obojętne na innych, ale ma, jak się wydaje, nieradzących sobie w życiu w pogardzie, nie tylko zatrzaskując przed nimi drzwi swoich domów, ale także unikając wszelkich kontaktów z nimi. Zatem jeśli chcemy, aby edukacja moralna rzeczywiście miała miejsce, to trzeba w niej eksponować nie historyczne przykłady, ale płynące z chwili obecnej, możliwe do natychmiastowego skonfrontowania z treściami przekazu internetowego.

Łatwo oczywiście się mówi o wzajemnym zaufaniu i współdziałaniu, ale jak propagować te wartości, skoro wszędzie mowa jest o bezpieczeństwie, które mają 
nam zapewnić inni. W sensie dosłownym nikt nie czuje się bezpieczny w świecie realnym, taka możliwość jest dostępna chyba już tylko w sieci. Teoretycy kultury słusznie zatem alarmują: „Zwróćmy uwagę: nieomal już się dziś nie mówi o rozwoju osobowości, a o »zasobach ludzkich «, »inwestowaniu w człowieka«, »kapitale ludzkim «, »aktywach ludzkich «. Rynek po prostu nazywa to po swojemu, zawłaszcza terminologię humanistyczną, bo chodzi właśnie o panowanie symboliczne" (Krzysztofek, 2001: 43). A przecież istnieją wartości konsolidujące ludzi, uczące ich współdziałania i prowadzące do walki o coś, w co się wierzy. Wydaje się jednak, że władze polityczne najbardziej obawiają się ponownego zrodzenia ruchu społecznego tak masowego i zdecentralizowanego, jakim była tzw. pierwsza Solidarność. Jeśli tak jest rzeczywiście, to najmniej zainteresowanym prowadzeniem realnej edukacji moralnej czynnikiem jest władza polityczna. Można nawet mniemać, że czuje się ona zagrożona wszelkimi możliwościami konsolidacji społeczeństwa wokół wspólnie wyznawanych wartości, a najlepiej według niej byłoby, gdyby społeczeństwo składało się z samych indywidualistów troszczących się tylko o własny interes.

Tego typu refleksje znajdujemy także u współczesnych filozofów, którzy nie tyle nawołują do dokonywania zmian w sferze moralnej, co dostrzegają pewien automatyzm w ich zachodzeniu. Dla przykładu Leszek Kołakowski pisał o coraz częstszym kwestionowaniu tradycyjnych wskazań moralnych w samej zasadzie i że z tej racji powinny one być zmienione lub zniesione (Kołakowski, 1984: 118.). Z drugiej zaś strony Kołakowski zauważa, że działanie zespołowe ciągle traci na znaczeniu w kulturze, gdyż niegdyś wiele ludzi było zaangażowanych w realizację jednego zamierzenia, które współcześnie jednostka dzięki wykorzystywaniu osiągnięć nowoczesnej nauki i techniki potrafi wykonać sama. Czynnik ludzki przestaje w taki sposób być siłą napędową współczesnej cywilizacji, gdyż mechanizm ją napędzający staje się coraz bardziej bezosobowy.

Obecna dyskusja nad edukacją moralną młodego pokolenia wydaje się jednak ciągle kontynuacją dyskusji znanych z historii. Już blisko sto lat temu zauważono, że: „W pieczy nad młodem pokoleniem ludzi [...] bywają jednak epoki, w których społeczną wartość samego przez się wychowania przygłuszały momenty kształcenia zdolności umysłu i wzbogacania wiedzy; symptomem tego kierunku jest przeładowanie programów szkolnych i utylitarny charakter przedmiotów nauczania” (Zmigryder-Konopka, 1934: 1). To właśnie oderwanie od najważniejszego dla ludzi współdziałania społecznego powoduje niejako mentalny nawrót do epoki pierwotnej, gdy liczyła się przede wszystkim zdolność do zapewnienia sobie indywidualnego bezpieczeństwa. Brutalna walka o byt traktowana jest także dziś jako droga do zapewnienia sobie korzystniejszego położenia w społeczeństwie, to zaś skutkuje ograniczeniem kontaktów społecznych do absolutnego minimum bądź 
do zapewnienia tylko ich namiastki, jaką oferują media społecznościowe. Wszyscy bowiem dążą do osiągnięcia sukcesu za każdą cenę, a miarą jego jest to, aby nie dać się wyprzedzić innym.

\section{Dygresje historyczne}

Pomimo wszelkich trudności w sferze animowania i formowania edukacji moralnej warto się odwołać do Kazimierza Twardowskiego, założyciela dominującej dziś w polskiej filozofii szkoły lwowsko-warszawskiej. Zobaczymy tradycyjne podejście do tej dziedziny. Jego zdaniem, zwieńczeniem edukacji młodego człowieka jest zdolność do samodzielnego sformułowania zasad etyki. Twardowski nazwał edukację moralną technologią moralną, gdyż zakładał, że ma ona charakter mechanicznego przekazywania uczniom gotowych treści ${ }^{5}$.

Głosił, że celem edukacji powinien być absolwent zdolny do samodzielnego podejmowania decyzji, a szkoła miała dostarczyć mu wiedzę umożliwiającą przewidywanie skutków własnych poczynań. A zatem celem zabiegów edukacyjnych ma być ukształtowanie u wychowanków zdolności do postępowania niezależnego od zewnętrznych wzmocnień. Stąd nauczyciele wszystkich szczebli nauczania mają być żywotnie zainteresowani wszelkimi próbami czynionymi w tym zakresie.

Według powyższej koncepcji szkoły mają zadanie nauczania, jak należy postępować, aby być aprobowanym przez społeczeństwo. Przy takim założeniu edukacja w sferze etyki metodycznie nie odbiegała więc od nauczania pozostałych przedmiotów szkolnych. Poglądy Twardowskiego na temat edukacji moralnej (etycznej) były konsekwencją jego przekonania o tym, że filozofia jest jednolitą nauką. Stanowi to konsekwencję wyodrębnienia przez niego trzech rodzajów faktów, które podlegają władzy tylko rozumu. Są to fakty etyczne, estetyczne i logiczne. Tylko rozum wydaje o nich sądy, a więc tylko od niego zależą. Choć tego rodzaju sądy dotyczą faktów, to rozum musi je oceniać wedle zasady przeciwieństwa, coś jest lub czegoś nie ma. Ludzie w zależności od swojego wyposażenia biologicznego i intelektualnego mogą być zatem $w$ swoich sądach ze sobą niezgodni.

Twardowski był przekonany, że musi tak być, bo inaczej teoria ewolucji nie miałaby sensu. Te trzy rodzaje faktów podlegają ocenie jednej z władz rozumu: „Po pierwsze ocenianie rzeczy ze stanowiska etycznego, na podstawie sumienia; po drugie ocenianie rzeczy ze stanowiska estetycznego na podstawie smaku, poczucia piękna;

5 Sam Twardowski nie zajmował się jednak technologią moralną, ale próbował to z powodzeniem czynić jego uczeń, Tadeusz Kotarbiński. 
po trzecie ocenianie rzeczy ze stanowiska logicznego na podstawie rozumu. Każdy z tych trzech rodzajów oceniania obraca się między dwiema ostatecznościami: pierwszy między dobrem a złem, drugi między pięknem a brzydkiem, trzeci między prawdą a fałszem" (Twardowski, 1927: 348).

Człowiek racjonalny wykorzystuje zatem swój rozum po to głównie, aby te władze nieustannie doskonalić. Z tej racji dorastający człowiek musi „szukać etyki”, bo chcąc samodzielnie kierować swoim życiem, musi się na to zdobyć. Nigdzie też nie znajdzie rozwiązania w postaci gotowej, a możliwość sformułowania własnej etyki zależy wyłącznie od tego, czy w ogóle się jej poszukuje. Nie wszyscy jednak tego chcą. Jedni z tego powodu, że nie potrafią, a inni z czystego wygodnictwa. Skazują się wtedy wyłącznie na naśladownictwo, na powielanie tego, co już było i jest znane.

W mniemaniu Twardowskiego, gdyby wszyscy tacy byli, to zapewne ludzie chyba nigdy by nie zeszli z drzew. Skoro jednak tak się stało, to znak, że prawdziwe człowieczeństwo polega na samodzielnym kierowaniu własnym życiem, a nie powielaniu gotowych wzorców. Dla Twardowskiego było zatem czymś oczywistym, że chcieć to móc, a zatem można pożądać własnych rozwiązań wyłącznie wówczas, gdy się potrafi je zaprojektować w postaci celu do osiągnięcia.

Wymagało to - w jego przekonaniu - ukończenia całego cyklu nauczania, czyli uzyskania wykształcenia na poziomie akademickim. Brak wykształcenia niejako automatycznie miał powodować, że dana jednostka była skazana tylko na powielanie tego, co potrafiła dobrego dla siebie dostrzec w postępowaniu ludzi, którzy potrafili zdobyć się na taki wysiłek. W ten sposób zakładał, że moralne postępowanie może być wynikiem zewnętrznego wpływu lub rezultatem własnego wyboru.

\section{Twardowski i Dewey}

Co interesujące, w poglądach na edukację moralną istnieje korelacja pomiędzy przekonaniami Twardowskiego i Johna Deweya, amerykańskiego pragmatysty, który odegrał znaczną rolę w ruchu sprzyjającym rozwojowi edukacji moralnej w USA. Istotne jest tu zwłaszcza to, że ich poglądy przyjęli w zasadzie wszyscy wychowankowie szkoły lwowsko-warszawskiej, a ci wywierają do dziś przemożny wpływ na całą polską filozofię i etykę, a więc pośrednio także na dyskusje o edukacji moralnej.

Dewey odróżnia dwa procesy. Pierwszy to proces wyposażania młodego pokolenia w wartości i pojęcia moralne (skłanianie go do internalizacji wartości), a drugi to dostarczenie mu wiedzy o pojęciach moralnych i wyjaśnienie, dlaczego inni zachowują się akurat tak, a nie inaczej i jak ludzie powinni się zachowywać, chcąc zasłużyć na miano moralnych. 
Według niego konieczne jest odróżnianie tych dwóch obszarów. Inaczej dojdzie do nieuzasadnionej krytyki edukacji moralnej prowadzonej w szkołach ze strony osób postronnych, które poszukują w programach określonej liczby godzin poświęconych na formalną edukację moralną. Jeśli ich nie znajdują, oskarżają szkołę o lekceważenie tej sfery wychowania młodego pokolenia, a często nawet, jeśli takie zajęcia są prowadzone, spotyka się to z ich krytyką za rzekome marginalizowanie tego typu edukacji. „Nauczyciele zaś zarzuty tego rodzaju odczuwają jako niesprawiedliwość, utrzymując nie tylko, że »uczą moralności«, lecz, że uczą jej w każdej porze dnia, pięć dni w tygodniu" (Dewey, 1921: 5).

Paradoksalnie Dewey podkreślał, że instytucjonalna edukacja moralna w nikłym stopniu wpływa na jakość postępowania wychowanków. Wynika to z tej racji, że do szkoły trafili oni w znacznym stopniu z już wyrobionymi postawami moralnymi. A zatem szkoła głównie wzmacnia już ukształtowane charaktery, a nie dopiero je formuje, co jest konsekwencją faktu, że zarówno wychowanie moralne w domach rodzinnych, jak i edukacja szkolna w swej istocie realizują te same cele. I inaczej być nie może pod groźbą rozchwiania kondycji moralnej młodego pokolenia.

Szkoła pod względem moralnym jest zatem kontynuacją wychowania moralnego młodego pokolenia prowadzonego jeszcze w okresie przedszkolnym. Ma ona zatem obowiązek „tak kształcić dziecko, aby miało władzę nad sobą w tym stopniu, by mogło być samodzielnem, by nie tylko przystosować się mogło do zmian zachodzących, lecz także posiadało możność oddziaływania na nie i kierowania niemi” (Dewey, 1921: 9). Dlatego też uważał, że dzieci muszą być tak samo kształtowane pod względem moralnym jak dorośli, bo szkoła przygotowuje je przede wszystkim do samodzielnego życia w zróżnicowanym społeczeństwie. Zauważał także łatwość wypaczenia szkolnej edukacji moralnej, która zamiast uczyć zgodnego i twórczego współdziałania, może kształtować egoistyczny pęd do niezdrowego współzawodnictwa. Szkoła bowiem kształtować ma przede wszystkim kulturę, a dopiero w dalszej kolejności wiedzę i dyscyplinę moralną. Każdy przedmiot nauczania ma także znaczenie moralne, jeśli tylko "daje zrozumienie życia społecznego" (Dewey, 1921: 28).

\section{$* * *$}

Obecne polskie spory o kształt edukacji etycznej młodego pokolenia przypominają w wielu istotnych punktach sytuację z przełomu lat 50. i 60. XX wieku. Spór ten został jakby przeniesiony z płaszczyzny merytorycznej do ideologicznej. W istocie bowiem chodzi o to, czy samo nauczanie religii w szkole nie wyczerpuje już tego, co można byłoby powiedzieć podczas zajęć z etyki (ewentualnie przyszłej edukacji moralnej). Różnica pomiędzy tym okresem a sytuacją obecną oczywiście istnieje 
i ma ona znaczenie fundamentalne. Wówczas bowiem to państwo było zaangażowane w ten spór i za pomocą działań administracyjnych wspomagało zwolenników uniwersalizmu etycznego.

Ich zwycięstwo było jednak pyrrusowe, bo tak naprawdę usunąwszy religię ze szkół nie wprowadzono w to miejsce etyki tylko zajęcia z propedeutyki filozofii, a potem nawet $\mathrm{z}$ niej zrezygnowano, przenosząc treści etyczne do zakresu wychowania obywatelskiego. W taki sposób władze oświatowe milcząco uznały, że nie ma edukacji moralnej bez religii. W dyskusjach nad przeszłością edukacji moralnej w polskiej szkole nie można tych doświadczeń zlekceważyć, bo obecna sytuacja w wielu momentach przypomina ówczesny stan rzeczy.

Ostatecznie bowiem w edukacji moralnej chodzi o, jak to dobitnie wyraził Karl Popper, krytyczną aprobatę otaczającego świata. Świat jest otwarty na wszelkie racjonalne innowacje, ale wymaga to gotowości młodego pokolenia na wprowadzanie takich zmian. „Bycie optymistą jest obowiązkiem człowieka, ponieważ tylko dzięki optymizmowi można być aktywnym i dążyć do osiągnięcia swoich celów. Jeśli ktoś jest pesymistą, poddał się, zrezygnował. Dlatego należy być optymistą, trzeba patrzyć na świat z punktu widzenia tego, jaki jest piękny, i jak można uczynić go lepszym” (Chmielewski, 1995: 246).

\section{Bibliografia}

Chmielewski, A. (1995). Filozofia Poppera. Analiza krytyczna. Wrocław: Wydawnictwo Uniwersytetu Wrocławskiego.

Dewey, J. (1921). Zasady moralne w wychowaniu, przeł. W. Hofman. Lwów: Wydawnictwo Zakładu Narodowego im. Ossolińskich.

Kołakowski, L. (1984). Mała etyka, w: Czy diabeł może być zbawiony i 27 innych kazań. Londyn: Aneks: 83-120.

Krzysztofek, K. (2001). Prywatyzacja moralności w społeczeństwie końca milenium, w: I. Wojnar (red.), Dylematy etyczne dnia dzisiejszego i przyszłości. Warszawa: Dom Wydawniczy ELIPSA: 40-59.

Pilch, T. (1999). Pedagogika w poszukiwaniu swych zadań i roli w budowaniu przyszłości, w: F. Adamski, A.M. de Tchorzewski (red.), Edukacja wobec dylematów moralnych wspótczesności. Kraków: Wydawnictwo UJ: 57-68.

Polanyi, K. (2001). The Great Transformation. The Political and Economic Origins of Our Time. Boston: Beacon Press.

Rosiękowiczowa, A. (1823). Nauka moralna dla kobiet. Warszawa: Nakładem i drukiem N. Glücksberga. 
Twardowski, K. (1927). Etyka wobec teorii ewolucji, w: K. Twardowski, Rozprawy i artykuły filozoficzne. Lwów: Księgarnia „Książnica-Atlas”.

Zybała, A. (2019). Edukacja moralna w oświacie - trendy i bariery. Studia z Polityki Publicznej, 4.

Zmigryder-Konopka, Z. (1934), Humanizm jako czynnik wychowania moralnego. Wiedza i Życie, 12: 3-11. 